\title{
Knowledge of undergraduate nursing students about human papillomavirus vaccine*
}

\author{
Conhecimento de graduandos em enfermagem sobre a vacina contra o papilomavírus \\ humano
}

Paula Hino ${ }^{1}$, Nailde Cristina de Freitas ${ }^{2}$, Priscilla Sete de Carvalho Onofre ${ }^{1}$, Katia Lacerda de Souza ${ }^{3}$, Jaqueline de Oliveira Santos ${ }^{1}$

Objective: to identify the knowledge that undergraduate nursing students have about human papillomavirus vaccine. Methods: field research, descriptive, cross-sectional. Sample composed of 100 undergraduate nursing students of a private university, with use of a questionnaire. Data were analyzed using descriptive statistics. Results: among participants, $98.0 \%$ reported that they knew the human papillomavirus vaccine, $65.0 \%$ recognized the types of viruses against which the vaccine gives protection, and $51.0 \%$ had knowledge about the age group that is targeted to receive the vaccine in the public healthcare network. As for the features of the administration of the vaccine, such as dosage, route of administration, contraindications and adverse events, a level of knowledge below $60.0 \%$ was observed. Conclusion: insufficient knowledge on the human papillomavirus vaccine was found among the students participating in the present study and this stresses the need to give more attention to the discussion about the prevention of cervical cancer during the training of future nurses.

Descriptors: Nursing; Colonic Neoplasms; Adolescent; Papillomavirus Vaccines.

Objetivo: identificar o conhecimento de graduandos em enfermagem sobre a vacina contra o papilomavírus humano. Métodos: pesquisa de campo, descritiva, transversal. Amostra composta por 100 alunos do curso de graduação em enfermagem de uma universidade privada, utilizando-se um questionário. Dados analisados por meio da estatística descritiva. Resultados: $98,0 \%$ dos participantes referiram que conheciam a vacina contra o papilomavírus humano, 65,0\% reconheciam os tipos de vírus que a vacina protege e 51,0\% possuíam conhecimento quanto à faixa etária destinada a recebê-la na rede pública. Quanto às particularidades da administração da vacina, como dosagem, via de administração, contraindicações e eventos adversos observou-se conhecimento inferior a $60,0 \%$. Conclusão: constatou-se conhecimento deficiente dos graduandos participantes sobre a vacina contra o papilomavírus humano, ressaltando a necessidade de enfatizar a discussão acerca da prevenção do câncer do colo do útero durante o período de formação de futuros enfermeiros.

Descritores: Enfermagem; Neoplasias do Colo; Adolescente; Vacinas contra Papillomavírus.

\footnotetext{
* Extracted from the Work of Course Conclusion entitled "Conhecimento de graduandos em enfermagem sobre a vacina contra o papilomavírus humano", Universidade Paulista, 2015.

${ }^{1}$ Universidade Paulista. São Paulo, SP, Brazil.

${ }^{2}$ Instituto Dante Pazzanese de Cardiologia. São Paulo, SP, Brazil.

${ }^{3}$ Corpo de Saúde da Marinha do Brasil. Rio de Janeiro, RJ, Brazil. 


\section{Introduction}

Human papillomavirus deserves special attention from public health agencies, health professionals and the public because it is a virus with oncogenic potential. Most cases of cervical cancer are related to the presence of human papillomavirus in the body of the woman. It is also associated with the appearance of warts on the genitals, precancerous lesions of the anogenital tract and head and neck neoplasias ${ }^{(1-3)}$.

There are more than 150 subtypes of human papillomavirus, of which 40 can infect the genital tract. The virus subtypes are classified according to the oncogenic potential, which may be of high, medium and low risk. The subtypes 16 and 18 are considered potentially oncogenic and account for approximately $70.0 \%$ of cases of cervical cancer, $90.0 \%$ of cancer in the anus, $60.0 \%$ in the vagina and $50.0 \%$ of cases of cancer of the vulva worldwide ${ }^{(3)}$.

It is estimated that 16,340 new cases of cervical cancer occur in Brazil in 2016, representing an incidence rate of 15.9/100,000 inhabitants, ranking the third position among the most frequent types of cancer in women. Currently, cervical cancer is the second more incident type of cancer in the North (24 cases/100,000 inhabitants), Midwest (20.1 cases $/ 100,000$ inhabitants) and Northeast (19.5 cases $/ 100,000$ inhabitants), the third in the Southeast (11.3 cases/100,000 inhabitants) and the fourth in the South $\left(15.2\right.$ cases $/ 100,000$ inhabitants) ${ }^{(3)}$.

Risk factors for the development of cervical cancer are: early onset of sexual activity, multiple partners, multiparity, genetic predisposition, immune status, poor hygiene and nutrition, smoking, use of oral contraceptives, coinfection with Chlamydia trachomatis and human immunodeficiency virus, among others ${ }^{(1,4)}$

The main form of transmission is through sexual contact, including oral-genital, genital-genital or genital manual contact. Condom use during sex is a way to reduce infection by human papillomavirus.
However, this practice does not eliminate the risk of contamination, since contact with the skin of vulvar regions, perineal, perianal and scrotal can also contaminate an individual ${ }^{(3)}$. Clinical detection of human papillomavirus is made through the identification of warts, and some cases, diagnosed by peniscopy and colposcopy. Subclinical diagnosis of lesions is made by cytology, and is confirmed by laboratory tests and molecular diagnostics, such as hybrid capture test ${ }^{(5)}$.

Epidemiological data show the need for actions to prevent cervical cancer. The vaccine against the most oncogenic virus has been effective in combating the disease, with significant cost benefit. This has been the strategy used by some countries since 2006 after approval by the US agency responsible for regulating drugs and food, named Food and Drug Administration. In that same year, the National Health Surveillance Agency regulates its commercialization in Brazil. Two types of human papillomavirus vaccines are sold in Brazil: the bivalent, which protects against the viral subtypes 16 and 18 and the tetravalent that acts against subtypes $6,11,16$ and $18^{(1,6)}$.

In 2014, the Ministry of Health of Brazil included the tetravalent vaccine for girls between 9 and 13 years old in the national vaccination calendar in order to prevent cervical cancer. The immunization should preferably be carried out before the beginning of sexual activity because it protects against strains, before exposure. For this reason, this age range was chosen. The vaccine efficacy is $98.8 \%$ and according to the National Cancer Institute, it is expected that at least $80.0 \%$ of the target population be vaccinated in order to reach the goal of reducing the incidence of cervical cancer in the country ${ }^{(3,5)}$.

Considering the recent availability of human papillomavirus vaccine in the public health system and the importance of the nurse's role in the control of uterine cancer, this study aimed to identify the knowledge that undergraduate nursing students of a higher education institution have on human papillomavirus vaccine. 


\section{Methods}

Field study, descriptive, cross-sectional. One hundred students enrolled in Nursing bachelor's course from a private higher education institution located in the southern area of São Paulo, Brazil participated in this study. The sample was defined considering $25.0 \%$ of the students enrolled in the morning shift by applying the non-probability sampling technique, by convenience, subject to availability of the students to participate in the study. The following inclusion criteria were considered: age of 18 years or above and be enrolled in the institution in the morning shift, regardless of in which semester the student was at the time of data collection.

Data collection took place between August and September 2015, using a questionnaire with closed questions concerning the socio-demographic profile of the students and about the knowledge on human papillomavirus vaccine. The data collection instrument was developed by the own researchers based on literature relevant to the subject. The information obtained was inserted in an Excel software $^{\circledR}$ spreadsheet and were analyzed using descriptive statistics. Results are presented in tables, according to absolute and relative frequency. The software used to calculate the $95.0 \%$ confidence intervals was Stata 12.0.

The study complied with the formal requirements contained in the national and international regulatory standards for research involving human beings.

\section{Results}

The study included 100 undergraduate Nursing students, of which $25.0 \%$ were enrolled in the first year, $24.0 \%$ in the second, $17.0 \%$ in the third and, finally, $34.0 \%$ in the fourth year. Regarding the socio-demographic profile of the research subjects, $85.0 \%$ were female and $51.0 \%$ were aged between 18 and 27 years. Most students reported family income between one and three minimum salaries (51.0\%) and reported not having children (61.9\%). It was observed that $42.0 \%$ of participants had working activities in the health area, exercising the function of nursing assistant/technician, and 35.0\% reported being dedicated only to academic studies (Table 1).

Table 1 - Socio-demographic profile of Nursing students from a private institution

\begin{tabular}{|c|c|c|}
\hline Variable & n (\%) & CI (95\%) \\
\hline \multicolumn{3}{|l|}{ Gender } \\
\hline Female & $85(85.0)$ & $76.5-91.4$ \\
\hline Male & $15(15.0)$ & $8.6-23.5$ \\
\hline \multicolumn{3}{|l|}{ Age group (years) } \\
\hline $18-27$ & $51(51.0)$ & $41.0-61.0$ \\
\hline $28-38$ & $36(36.0)$ & $2.64-45.6$ \\
\hline $39-49$ & $12(12.0)$ & $5.5-18.5$ \\
\hline $50-60$ & $1(1.0)$ & $0.0-3.0$ \\
\hline \multicolumn{3}{|l|}{ Marital status } \\
\hline Single & $63(63.0)$ & $53.4-72.6$ \\
\hline Married/Common-law marriage & $26(26.0)$ & $17.3-34.7$ \\
\hline Divorced & $9(9.0)$ & $3.3-14.7$ \\
\hline Widow/widower & $2(2.0)$ & $0.0-4.8$ \\
\hline \multicolumn{3}{|l|}{ Family income (in $\mathrm{n}$ o of salaries) } \\
\hline No income & $9(9.0)$ & $3.3-14.7$ \\
\hline$<1$ & $2(2.0)$ & $0.0-4.8$ \\
\hline $1-3$ & $51(51.0)$ & $41.0-61.0$ \\
\hline $4-6$ & $32(32.0)$ & $22.7-41.3$ \\
\hline $7-9$ & $5(5.0)$ & $0.7-9.3$ \\
\hline$>10$ & $1(1.0)$ & $0.0-3.0$ \\
\hline \multicolumn{3}{|l|}{ Number of children } \\
\hline None & $60(61.9)$ & $51.4-71.5$ \\
\hline $1-2$ & $30(30.9)$ & $21.9-41.1$ \\
\hline $3-5$ & $7(7.2)$ & $3.0-14.3$ \\
\hline No information & 3 & $0.0-0.9$ \\
\hline \multicolumn{3}{|l|}{ Professional area } \\
\hline Health & $42(42.0)$ & $32.2-52.3$ \\
\hline Student & $35(35.0)$ & $25.7-45.2$ \\
\hline Management & $15(15.0)$ & $8.6-23.5$ \\
\hline Market & $4(4.0)$ & $1.1-9.9$ \\
\hline Total & $100(100.0)$ & \\
\hline
\end{tabular}


Regarding the knowledge of students about the meaning of the acronym of the human papillomavirus, $75.0 \%$ participants recognized its meaning. Most (98.0\%) claimed to have knowledge of the existence of a vaccine against human papillomavirus, $83.0 \%$ said it was composed of inactivated live virus and $71.4 \%$ knew the four subtypes of virus against which the vaccine offers protection. It was observed that $51.0 \%$ of the students had good knowledge about the age group recommended to receive the vaccine in the public health system (Table 2).

Table 2 - Knowledge that students enrolled in a Nursing private institution have on human papillomavirus

\begin{tabular}{|c|c|c|}
\hline Variable & n (\%) & CI* $(95 \%)$ \\
\hline \multicolumn{3}{|c|}{ Knowledge about the existence of the vaccine } \\
\hline Yes & $98(98.0)$ & $93.0-99.8$ \\
\hline No & $2(2.0)$ & $0.0-4.8$ \\
\hline \multicolumn{3}{|l|}{ Composition } \\
\hline Inactivated live virus & $83(83.0)$ & $74.1-89.8$ \\
\hline Live virus & $15(15.0)$ & $8.6-23.5$ \\
\hline Dead bacteria & $2(2.0)$ & $0.0-4.8$ \\
\hline \multicolumn{3}{|l|}{ Protection against } \\
\hline $6,11,16$ and 18 & $65(71.4)$ & $61.0-80.4$ \\
\hline $6,16,45$ and 58 & $14(15.4)$ & $8.7-24.5$ \\
\hline $39,49,56$ and 58 & $7(7.7)$ & 3.1 to 15.2 \\
\hline $31,34,45$ and 52 & $5(5.5)$ & $1.8-12.4$ \\
\hline No information & 9 & $0.4-16.4$ \\
\hline \multicolumn{3}{|c|}{$\begin{array}{l}\text { Age group that must receive the vaccine } \\
\text { in the public health network (years) }\end{array}$} \\
\hline $9-13$ & $51(51.0)$ & $41.0-61.0$ \\
\hline $11-13$ & $28(28.0)$ & $19.5-37.9$ \\
\hline $9-11$ & $19(19.0)$ & $11.8-28.1$ \\
\hline $9-26$ & $2(2.0)$ & $0.0-4.8$ \\
\hline Total & $100(100.0)$ & \\
\hline
\end{tabular}

As for the administration of the vaccine, more than half of the study subjects (59.0\%) informed correctly the dosage of the vaccine, $40.0 \%$ said that three doses were needed to complete the immunization schedule, $15.0 \%$ answered correctly the interval between the doses and $57.0 \%$ knew the correct route of administration of the vaccine. Also, 53.0\%

of participants recognized that pregnant women and those who had anaphylactic reactions to components of the vaccine should not be immunized, while $23.0 \%$ mentioned that there is no contraindication for administration of the vaccine. Half of the participants showed correct knowledge of adverse vaccine events, such as local pain, swelling, redness, headache and syncope (Table 3).

Table 3 - Knowledge of students of a private Nursing institution about issues related to the vaccine against human papillomavirus

\begin{tabular}{|c|c|c|}
\hline Variable & n (\%) & CI* $(95 \%)$ \\
\hline \multicolumn{3}{|l|}{ Dose (ml) } \\
\hline 0.5 & $59(59.0)$ & $48.7-68.7$ \\
\hline 1.0 & $30(30.0)$ & $20.9-39.1$ \\
\hline 2.0 & $9(9.0)$ & $3.3-14.7$ \\
\hline 5.0 & $2(2.0)$ & $0.0-4.8$ \\
\hline \multicolumn{3}{|l|}{ Plan } \\
\hline Three & $40(40.0)$ & $30.2-49.8$ \\
\hline Two & $39(39.0)$ & $29.3-48.7$ \\
\hline One & $21(21,0)$ & $12.9-29.1$ \\
\hline \multicolumn{3}{|l|}{ Interval between doses (months) } \\
\hline 6 in 6 & $43(43.0)$ & $33.1-52.9$ \\
\hline Annual & $32(32.0)$ & $22.7-41.3$ \\
\hline 0.6 and 60 & $15(15.0)$ & $8.6-23.5$ \\
\hline 0.6 and 90 & $10(10.0)$ & $4.9-17.6$ \\
\hline \multicolumn{3}{|l|}{ Route of administration } \\
\hline Intramuscular & $57(57.0)$ & $47.1-66.9$ \\
\hline Subcutaneous injection & $37(37.0)$ & $27.4-46.6$ \\
\hline Intradermal & $4(4.0)$ & $1.1-9.9$ \\
\hline Oral & $2(2.0)$ & $0.0-4.8$ \\
\hline \multicolumn{3}{|l|}{ Contraindication } \\
\hline $\begin{array}{l}\text { Pregnantwomenandpeoplewithanaphy- } \\
\text { lactic reaction to the vaccine components }\end{array}$ & $53(53.0)$ & $42.8-63.0$ \\
\hline There is no contraindication & $23(23.0)$ & $15.2-32.5$ \\
\hline Acute febrile illness & $14(14.0)$ & $7.9-22.4$ \\
\hline Immunosuppressed & $7(7.0)$ & $2.9-13.9$ \\
\hline Breastfeeding & $3(3.0)$ & $0.6-8.5$ \\
\hline \multicolumn{3}{|l|}{ Adverse events } \\
\hline $\begin{array}{l}\text { Pain at the injection site, swelling, } \\
\text { erythema, headache and syncope }\end{array}$ & $50(50.0)$ & $39.8-60.2$ \\
\hline $\begin{array}{l}\text { Bronchospasm, fever, pain and redness } \\
\text { in the whole body }\end{array}$ & $1(1.0)$ & $0.0-3.0$ \\
\hline Pain and redness in the whole body & $5(5.0)$ & $0.7-9.3$ \\
\hline $\mathrm{N} / \mathrm{A}$ & $44(44.0)$ & $34.0-54.3$ \\
\hline Total & $100(100.0)$ & \\
\hline
\end{tabular}


It was found that almost all participants (99.0\%) indicated the need to use condoms during sexual intercourse to prevent human papillomavirus, and the examination of Pap smear for detection of the disease, even with the administration of the vaccine.

\section{Discussion}

An important limitation of this study was the fact that the results can not be generalized because they do not offer enough information to gauge the knowledge of nursing students about the vaccine against human papillomavirus, given the small sample size and its application in only one higher education institution.

The results regarding the socio-demographic profile of research subjects confirm the literature on the subject under study. There was a predominance of females, which is in line with other studies that have addressed the same theme ${ }^{(7-10)}$. With respect to age, the result of this research corroborates a study in another private university of the state São Paulo, Brazil, that had the same objective ${ }^{(7)}$. Research studies indicate that nursing undergraduate students of private institutions tend to be older than undergraduate students of public institutions of higher education ${ }^{(7-9)}$. Most participants (65.0\%) reported exercising paid work. This result contrasts with a descriptive study conducted in a private university in Fortaleza, Brazil, in which the majority of students received financial support from the family ${ }^{(9)}$.

It was found that the knowledge of students is lower than expected for most of the investigated issues. However, knowledge about the meaning of the acronym of the human papillomavirus was considered satisfactory, and the existence and composition of the vaccine.

Vaccination against human papillomavirus is extremely important for prevention of cervical cancer. In this sense, the findings of the present study show that the students had more knowledge of the existence of a vaccine against human papillomavirus
(98.0\%) when compared to undergraduate students of the Nursing course of the University of Bauru, Brazil, in which $51,0 \%$ of participants reported having knowledge of the existence of the vaccine ${ }^{(7)}$. Other studies showed insufficient knowledge of students about the human papillomavirus, which can negatively influence the vulnerability of this population to sexually transmitted infections ${ }^{(9-10)}$.

It is noteworthy that, in the last 10 years, Brazilians have started sexual life at earlier ages, on average, at 12 years old in the case of women and 16 , in the case of men ${ }^{(11)}$. Early sexual initiation and multiple partners are influenced by the media, which not always stresses the importance of safe sex. This favors contamination by human papillomavirus and other sexually transmitted infections ${ }^{(5,9)}$.

Thus, it is noted that $25.0 \%$ of sexually active people practice safe sex in all sexual relations ${ }^{(12)}$. In this sense, the vaccine against human papilloma virus may contribute to prevention of cervical cancer as it provides protection against the virus subtypes considered most oncogenic. However, control measures against risk factors can not be disregarded. These include the reduction of sexual partners and condom use in all sexual relations ${ }^{(9)}$.

In the present study, there was a deficit of knowledge related to the characteristics of the human papillomavirus vaccine, including the interval between doses and the vaccination plan, route of administration, contraindications, adverse events and age groups recommended to receive the vaccine in the public health network. These data corroborate the study conducted with nursing students at a university located in the border region of the United StatesMexico, which showed that the level of knowledge among participants was below expectations ${ }^{(8)}$.

Another study at a public university in São Paulo, Brazil, revealed lack of knowledge among nursing students about human papillomavirus and its relationship with cervical cancer. In this case, $60.3 \%$ participants reported to know the meaning of the acronym, $69.0 \%$ said they knew how transmission 
happens, and $20.7 \%$ recognized some signs and symptoms caused by the virus. Therefore, the need to improve the knowledge on this subject is evident in the training of future health professionals, so that they may provide a qualified service ${ }^{(5)}$.

When asked about health care and issues related to the vaccine, the undergraduate students understood that vaccination is a preventive measure, but that this does not turn the use of condoms in sexual relations and the realization of Pap smear unnecessary. Data from the present study are consistent with research that reveal that undergraduates advocate the use of condoms and the realization of the Pap smear as fundamental for the investigation of precursor lesions of cervical cancer ${ }^{(7,10)}$.

Research carried out on the international scene corroborates the findings of this research. Study carried out with 117 undergraduate students from a province of China revealed ignorance of the population about vaccine against human papillomavirus and cancer of the cervix, and less than half of the participants were willing to receive the vaccine. Therefore, the results of this study suggest low knowledge among Chinese young people about the preventive nature of the vaccine, indicating the need for educational interventions to promote public awareness and provide information about the vaccine and cervical cancer prevention ${ }^{(13)}$. Another survey conducted with university students and nurses found that they had some knowledge about cervical cancer and about the vaccine against human papillomavirus, although this was considered insufficient ${ }^{(14)}$.

The vaccine against human papillomavirus is a powerful tool in the fight against cervical cancer. Primary (immunization) and secondary (examination Pap smear) prevention play an important role in reducing the incidence rates of this cancer and the diagnosis in early stage of the disease has a positive impact on women's mortality rate ${ }^{(1)}$.

Noteworthy is the nurse's potential as a professional responsible to provide a service with high quality according to the real health needs of users, whether in activities of health promotion but also in disease prevention. Nursing care involves understanding the integrality of the human being, which should be performed since the moment of hosting the user, with qualified listening to the needs and health problems of the user, through activities of primary prevention up to the rehabilitation of the user.

In this sense, because the nurse has a closer contact with patients and with the population, this professional occupies a prominent role in activities to promote health and prevention of cervical cancer. Various strategies can reduce the risk factors. These include education groups with discussion topics that address sexuality, vulnerability and prevention of sexually transmitted infections and family planning, women's mobilization for self-care and a better quality of life, minimizing the difficulties of access to health services, among others ${ }^{(15)}$.

\section{Conclusion}

The results showed lack of knowledge of students on the various issues related to the vaccine against human papillomavirus. Because the research was carried out with undergraduate students of the health area and, therefore, people who have greater access to information on the subject under study, a different result was expected. It was found that the knowledge of students is lower than expected for most of the investigated issues. However, knowledge about the meaning of the acronym of the human papillomavirus, the existence and composition of the vaccine against human papillomavirus was satisfactory.

Considering the relevance of the work of nurses in the control of cervical cancer, we emphasize the need to develop strategies for greater disclosure of risk factors for developing this type of cancer among undergraduate students, as well as on ways of prevention against human papillomavirus infection, especially vaccination. 


\section{Collaborations}

Hino $\mathrm{P}$ participated in the project design, analysis and interpretation of data. Freitas NC, Onofre PSC and Souza KL contributed in writing the article and in relevant critical review of the intellectual content. Santos OJ contributed to the final approval of the version to be published.

\section{References}

1. Zardo GP, Farah FP, Mendes FG, Franco CAGS, Molina GVM, Melo GN, et al. Vacina como agente de imunização contra o HPV. Ciênc Saúde Coletiva. 2014; 19(9):3799-808.

2. Reis AAS, Monteiro CD, Paula LB, Santos RS, Saddi VA, Cruz AD. Papilomavírus humano e saúde pública: prevenção ao carcinoma de cérvice uterina. Ciênc Saúde Coletiva. 2010; 15(Supl.1):1055-60.

3. Instituto Nacional do Câncer. Câncer de colo de útero [Internet]. 2016 [citado 2016 ago 02]. Disponível em: http://www2.inca.gov.br/wps/ wcm/connect/tiposdecancer/site/home/colo_ utero/definicao

4. Ministério da Saúde (BR). Secretaria de Vigilância em Saúde. Departamento de Vigilância de Doenças Transmissíveis. Coordenação Geral do Programa Nacional de Imunizações. Guia prático sobre HPV: perguntas e respostas. Brasília: Ministério da Saúde; 2013.

5. Panobianco MS, Lima ADF, Oliveira ISB, Gozzo TO. Knowledge concerning HPV among adolescent undergraduate nursing students. Texto Contexto Enferm. 2013; 22(1):201-7.

6. Borsatto AZ, Vidal MLB, Rocha RCNP. Vacina contra o HPV e a Prevenção do Câncer do Colo do Útero: Subsídios para Prática. Rev Bras Cancerol. 2011; 57(1):67-74.

7. Cirilo CA, Barbosa ASAA, Zambrano E. Nível do comportamento e conhecimento sobre o papilomavírus humano entre universitários do curso de enfermagem. Rev Soc Bras Med Trop. 2010; 43(4):362-6.
8. Schomotzer GL, Reding KW. Knowledge and beliefs regarding human papillomavirus among College Nursing Students at a Minority-Serving Institution. J Community Health. 2013; 38(6):1106-14.

9. Andrade TMF, Martins MC, Gubert FA, Freitas CM. Conhecimento de acadêmicos de enfermagem em relação à infecção pelo papilomavírus humano e sua vacinação. J Bras Doenças Sex Trans. 2013; 25(2):77-81.

10. Silveira GA, Ferraz BG, Conrado GAM. Conhecimento dos universitários sobre HPV e câncer de colo de uterino em uma faculdade privada localizada no sertão de Pernambuco. Rev Saúde Coletiva Debate. 2012; 2(1):87-95.

11. Ministério da Saúde (BR). Atividade sexual e anticoncepção [Internet]. 2015 [citado 2015 out 30]. Disponível em: http://bvsms.saude.gov.br/ bvs/pnds/atividade_sexual.php

12. Ministério da Saúde (BR). Secretaria de Atenção em Saúde. Departamento de Ações Programáticas Estratégicas. Diretrizes nacionais para a atenção integral à saúde de adolescentes e jovens na promoção, proteção e recuperação da saúde. Brasília: Ministério da Saúde; 2010.

13. Gu C, Nicsolai LM, Yang S, Wang X, Tao L. Human papillomavirus vaccine acceptability among female undergraduate students in China: the role of knowledge and psychosocial factors. J Clin Nurs. 2015; 24(19):2765-78.

14. Topan A, Ozturk O, Eroglu H, Bahadir O, Harma M, Harma MI. Knowledge level of working and student nurses on cervical cancer and human papilloma virus vaccines. Asian Pac J Cancer Prev. 2015; 16(6):2515-9.

15. Narchi NZ, Janicas RCSV, Fernandes RAQ, Amaral LMP. Prevenção e controle do câncer de colo do útero. In: Fernandes RAQ, Narchi NZ. Enfermagem e saúde da mulher. Barueri: Manole; 2013. p.15480. 